\title{
Postcapillary Venule Endothelial Cells in Kidney Express a Multispecific Chemokine Receptor That Is Structurally and Functionally Identical to the Erythroid Isoform, Which Is the Duffy Blood Group Antigen
}

\author{
Terence J. Hadley, ${ }^{\star \|}$ Zhao-hai Lu, ${ }^{\ddagger}$ Kazimiera Wasniowska, ${ }^{\star}$ Alvin W. Martin, ${ }^{\ddagger}$ Stephen C. Peiper, ${ }^{\ddagger}$ Joseph Hesselgesser, ${ }^{\S}$ \\ and Richard Horuks \\ *Henry Vogt Cancer Research Institute of the James Graham Brown Cancer Center, Departments of Medicine and ${ }^{\ddagger}$ Pathology and \\ Laboratory Medicine, University of Louisville School of Medicine, Louisville, Kentucky 40292; "Veterans Administration Medical Center, \\ Louisville, Kentucky 40207; and ${ }^{8}$ Department of Protein Chemistry, Genentech Inc., South San Francisco, California 94080
}

\begin{abstract}
The human erythrocyte chemokine receptor has recently been shown to be identical to the Duffy blood group antigen and is expressed in multiple organs, including kidney. Here we have examined the molecular properties of the renal isoform. Immunoblot analysis of erythrocyte and kidney detergent lysates, with a monoclonal antibody (Fy6) to the Duffy antigen, revealed that the renal isoform had a molecular mass of 43-45 $\mathrm{kD}$, which could be distinguished from that observed in erythroid cells (38-47 kD). Chemical crosslinking of kidney membranes to ${ }^{125}$ I-melanoma growth stimulatory activity (MGSA) indicated that the renal chemokine receptor had a molecular mass of 38-45 $\mathrm{kD}$. Binding of ${ }^{125}$ I-labeled MGSA to kidney membranes was competitively inhibited by the addition of unlabeled MGSA, IL-8, regulated on activation, normal $T$ expressed and secreted, and monocyte chemotactic protein-1. Scatchard analysis of MGSA binding showed that the chemokine receptor from renal tissues had a binding affinity of $3.5 \mathrm{nM}$ similar to that observed for the erythroid isoform (5-10 nM). The primary structure of the renal chemokine receptor predicted from the nucleotide sequence of cDNA from renal tissues is identical to that reported for the erythroid isoform. Immunocytochemical staining of kidney with Fy6 localized expression to endothelial cells present in postcapillary venules. These studies implicate the Duffy antigen/chemokine receptor in the complex interactions between postcapillary endothelial cells and granulocytes, which are modulated by pro-inflammatory chemokines. (J. Clin. Invest. 1994. 94:985-991.) Key words: interleukin-8 - melanoma growth stimulatory activity $\cdot$ cytokine $\bullet$ inflammation $\cdot$ diapedesis
\end{abstract}

\section{Introduction}

The chemokines are a family of pro-inflammatory molecules that have a variety of biological properties including leukocyte chemotaxis and activation (1-3). The family is characterized by the presence of four conserved cysteine residues and has

Address correspondence to Richard Horuk, Ph.D., Department of Protein Chemistry, Genentech Inc., 460 Point San Bruno Blvd., South San Francisco, CA 94080.

Received for publication 15 March 1994 and in revised form 25 May 1994.

The Journal of Clinical Investigation, Inc

Volume 94, September 1994, 985-991 been classified into two separate groups dependent on whether the first two conserved cysteine residues are separated by an intervening amino acid (C-X-C) or whether they are adjacent (C-C) $(1,2)$. The C-X-C class members include IL-8, melanoma growth stimulatory activity (MGSA), ${ }^{1}$ and platelet factor 4 (PF4), while the $\mathrm{C}-\mathrm{C}$ class members include regulated on activation, normal $\mathrm{T}$ expressed and secreted (RANTES); monocyte chemotactic protein-1 (MCP-1); and macrophage inflammatory protein-1 (MIP-1) $\alpha$ and $\beta$.

The chemokines produce their biologic effects by interacting with specific receptors on the surface of their target cells (13). Chemokine receptors can be grouped into two separate classes based on their ligand specificity. The first class belongs to the seven transmembrane spanning family of G-protein coupled receptors and binds either C-X-C or C-C chemokines (46 ). The second class is exemplified by the erythrocyte chemokine receptor which has a broader ligand specificity and can accommodate both $\mathrm{C}-\mathrm{X}-\mathrm{C}$ and $\mathrm{C}-\mathrm{C}$ chemokines $(7,8)$.

Recently the erythrocyte chemokine receptor has been shown to be identical to the Duffy blood group antigen $(9,10)$. The Duffy blood group antigen was first identified serologically as the target of alloantibodies that can cause posttransfusion hemolytic reactions (11). It was subsequently identified and characterized as a $35-43-\mathrm{kD}$ membrane glycoprotein $(12,13)$ which is necessary for the invasion of human erythrocytes by the monkey malaria Plasmodium knowlesi (14) and the human malaria, Plasmodium vivax $(15,16)$. Production of an anti-Duffy monoclonal antibody, anti-Fy6, (17) facilitated the purification and the subsequent cloning of the cDNA for the Duffy antigen receptor for chemokines (DARC) $(18,19)$. The nucleotide sequence of the cDNA encoding the DARC predicts a primary structure with novel topologic features, that include an amino terminal extracellular domain, nine potential transmembrane spanning regions, and a cytoplasmic carboxyl-terminal tail (19).

While transcripts encoding an isoform of the chemokine receptor can be detected in polyadenylated RNA from kidney and spleen (19), the subpopulation of cells that express the receptor has not been localized and the functional relationship of the renal and erythroid isoforms has not been resolved. We performed experiments to identify the cell types in kidney that express this receptor, as well as studies to determine ligand binding characteristics, immunologic identity, and primary structure of the renal isoform.

1. Abbreviations used in this paper: DARC, Duffy antigen receptor for chemokines; MCP-1, monocyte chemotactic protein-1; MGSA, melanoma growth stimulatory activity; MIP-1, macrophage inflammatory protein-1; PF4, platelet factor 4; RANTES, regulated on activation, normal $\mathrm{T}$ expressed and secreted. 


\section{Methods}

Materials. ${ }^{125} \mathrm{I}-\mathrm{IL}-8$ and ${ }^{125} \mathrm{I}-\mathrm{MGSA}$ (specific activity $2,200 \mathrm{Ci} / \mathrm{mmol}$ ) were obtained from New England Nuclear (Boston, MA). Unlabeled IL-8 and MGSA were purified as previously described $(8,20)$. Enriched human erythrocytes from outdated blood were obtained from Peninsula Blood Bank (Burlingame, CA). Reagents for electrophoresis were from Bio Rad Laboratories (Richmond, CA) and FMC BioProducts (Vallensback, Denmark). All other reagent grade chemicals were from Sigma Chemical Co. (St. Louis, MO). The Fy6 monoclonal antibody to the Duffy blood group antigen was kindly provided by Dr. Margaret Nichols (New York Blood Center, New York) as a hybridoma culture supernatant containing $22 \mu \mathrm{g}$ per $\mathrm{ml}$ of IgG (17).

Isolation of erythrocytes and production of erythrocyte ghosts. Human erythrocytes were isolated from whole blood using standard techniques (21). Erythrocyte ghosts were prepared as described previously (8).

Procurement of human kidney. Human kidney was obtained at University of Louisville-affiliated Jewish Hospital according to a standard protocol whereby the operative consent form includes permission that the tissue can be used for research purposes after being thoroughly examined by the pathologist responsible for diagnostic evaluation of the specimen.

Preparation of cell membranes. Human kidney (2.7 grams) was

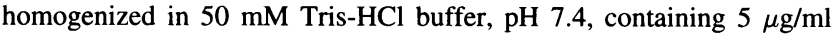
each of leupeptin and aprotinin, $0.1 \mathrm{mM}$ PMSF, $0.05 \mathrm{mM}$ Pefabloc, and $1 \mathrm{mM}$ EDTA (lysis buffer). The homogenate was centrifuged at $500 \mathrm{~g}$ for $20 \mathrm{~min}$. The pellet, which consisted of cell debris and nuclei, was discarded and the supernatant was centrifuged at $48,000 \mathrm{~g}$ for $30 \mathrm{~min}$. The resulting pellet, which consisted of total cell membranes was removed and resuspended to a final concentration of $7.5 \mathrm{mg}$ per $\mathrm{ml}$ in lysis buffer and stored at $-20^{\circ} \mathrm{C}$ until further use.

${ }^{125}$ I-labeled chemokine binding to kidney membranes. Human kidney membranes, $25-50 \mu \mathrm{g}$ of membrane protein, were incubated with ${ }^{125} \mathrm{I}$ labeled MGSA $(0.5 \mathrm{nM})$ and varying concentrations of unlabeled MGSA at $37^{\circ} \mathrm{C}$ for $1 \mathrm{~h}$ in PBS, pH 7.4. Binding was stopped by filtration through Whatman GF/C filters pretreated with $1 \%$ polyethyleneimine (Whatman Inc., Clifton, NJ). Filters were rinsed three times with $2 \mathrm{ml}$ ice cold PBS and counted in a gamma counter (Iso-Data 100; Isodata, Los Angeles, CA). Nonspecific binding was determined in the presence of $100 \mathrm{nM}$ unlabeled ligand. Binding data were analyzed by the Ligand program (22) as modified for the IBM PC (23).

Immunoblot analysis. Proteins were subjected to electrophoresis in $12 \%$ Novex precast minigels and transferred electrophoretically to Problot (Applied Biosystems Inc., Foster City, CA) in $10 \mathrm{mM}$ CAPS, pH 11 containing $10 \%$ methanol for $1 \mathrm{~h}$ at a current of $250 \mathrm{~mA}$. After transfer, the blots were incubated for $60 \mathrm{~min}$ at room temperature in 25 $\mathrm{mM}$ Tris- $\mathrm{HCl}, \mathrm{pH} \mathrm{7.4,} \mathrm{containing} 150 \mathrm{mM} \mathrm{NaCl}$ and $0.1 \%$ Tween 20 . The blots were then incubated overnight at $4^{\circ} \mathrm{C}$ with a $1: 1,000$ dilution of anti-Fy6. The blots were washed several times in Tris buffer and subsequently were incubated in a 1:20,000 dilution of horseradish peroxidase conjugated goat anti-mouse antibody (Tago Immunodiagnostics, Burlingame, CA) for $1 \mathrm{~h}$ at room temperature. After extensive washing, the blots were developed by the ECL chemiluminescence procedure, according to the manufacturer's instructions (Amersham Corp., Arlington Heights, IL).

Cross-linking of ${ }^{125}$ I-MGSA to cell membranes. Aliquots of the particulate membrane fraction $(150 \mu \mathrm{g})$ were incubated in the presence of $5 \mathrm{nM}$ of ${ }^{125} \mathrm{I}-\mathrm{MGSA}$, in the presence or absence of $1 \mu \mathrm{M}$ unlabeled MGSA, for $1 \mathrm{~h}$ at $37^{\circ} \mathrm{C}$ in PBS, pH 7.4. At the end of the incubation, the membranes were pelleted by centrifugation $(100,000 \mathrm{~g}$, for $15 \mathrm{~min})$, made up to the original volume in PBS, and chemically cross-linked with EDC (1-ethyl-3-[3-dimethylaminopropyl]carbodiimide hydrochloride) at a final concentration of $1 \mathrm{mM}$ for $1 \mathrm{~h}$ at room temperature. The membranes were then pelleted as described above and solubilized in SDS sample buffer in the presence of $50 \mathrm{mM}$ DTT for $3 \mathrm{~min}$ at room temperature and then analyzed by electrophoresis in $12 \%$ acrylamide gels containing SDS.

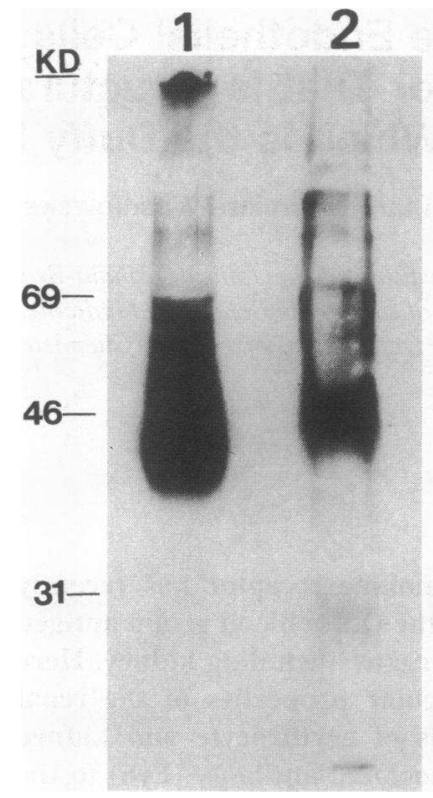

Figure 1. Western blot analysis of human kidney membranes. $150 \mu \mathrm{g}$ of erythrocyte ghosts (lane 1 ) and kidney cell membranes (lane 2) were subjected to SDS-PAGE, transferred electrophoretically to Problot, and analyzed as indicated in Methods.

cDNA synthesis and sequencing. Total cellular RNA was extracted from normal kidney and explants of Wilm's tumors using guanidinium isothiocyanate (24). RNA templates were reverse transcribed from an oligo deoxythymidilate primer using reverse transcriptase (Promega, Madison, WI). Single stranded cDNA was amplified by polymerase chain reaction using primers designed from the $5^{\prime}$ and $3^{\prime}$ non-coding sequences of the Duffy cDNA (13). Amplification products of the appropriate size $(1.2 \mathrm{~kb})$ were cloned into the TA vector (Invitrogen, La Jolla, $\mathrm{CA}$ ) and the nucleotide sequence was determined using the dideoxy chain termination technique with a Sequinase kit (US Biochemical Corp., Cleveland, $\mathrm{OH}$ ). The sequencing reaction was initially primed using forward and reverse universal primers to anneal to sites encoded in the vector. Reactions were analyzed by electrophoresis in a $6 \%$ polyacrylamide gel. Subsequent primers were designed from the nucleotide sequence that was derived.

Immunohistochemistry. Tissue blocks were obtained from the files of the University of Louisville Hospital. Sections were cut at $6 \mu \mathrm{m}$, deparaffinized with xylene, and rehydrated with ethanol. After washing with PBS, slides were incubated with anti-Fy6. Binding of the monoclonal antibody was detected by sequential incubations with a biotinylated secondary antibody, followed by complexes of avidin-biotinylated peroxidase. The reaction product was localized by incubation with the diaminobenzidine substrate.

\section{Results}

Renal tissues express the chemokine receptor polypeptide. Immunoblotting analysis was performed to determine whether the DARC is expressed by kidney tissues. Polypeptides present in membrane fractions from kidney tissues and erythrocytes were resolved by gel electrophoresis, transferred to hybridization membranes, and incubated with anti-Fy6. Detection of Duffyrelated proteins revealed a discrete band of $43-45 \mathrm{kD}$ in the kidney tissues and a heterogeneous, diffuse band ranging from 38 to $47 \mathrm{kD}$ in erythroid cells (Fig. 1).

The renal isoform of the DARC binds MGSA. Although the molecular mass of the anti-Fy6 reactive component of the kidney was similar to that of the erythrocyte, it appeared less heterogeneous (possibly due to differences in glycosylation). Also, since immunoblots were probed with a single monoclonal 


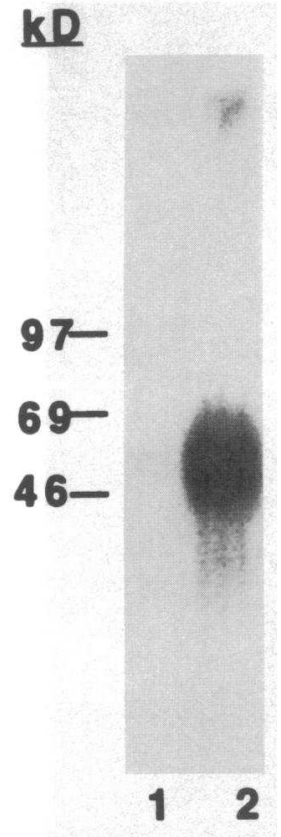

Figure 2. Covalent crosslinking of ${ }^{125}$ I-MGSA to human kidney membranes. Membranes prepared from human kidney were incubated with $5 \mathrm{nM}^{125} \mathrm{I}$-MGSA in the presence (lane 1), and in the absence (lane 2) of $1 \mu \mathrm{M}$ unlabeled MGSA. After $1 \mathrm{~h}$ at $4^{\circ} \mathrm{C}$ the membranes were washed free of unbound label. The bound ${ }^{125} \mathrm{I}$ MGSA was crosslinked by incubation with $\mathrm{EDC}$ for $1 \mathrm{~h}$ at $4^{\circ} \mathrm{C}$ and then washed with PBS before analysis by SDS-PAGE. $150 \mu \mathrm{g}$ of protein were applied to the gel. After electrophoresis the gels were dried down and subjected to autoradiography.

antibody, Fy6, it was possible that the anti-Fy6 reactive component of the kidney was not the DARC but rather a different molecule with a shared epitope. It was therefore important to demonstrate that the anti-Fy6 reactive molecule of the kidney, like that of the erythrocyte, is a chemokine receptor. We therefore performed chemical cross-linking experiments to determine whether this protein bound to labeled chemokines. Particulate membrane fractions of the renal tissues were incubated with ${ }^{125}$ I-labeled MGSA in the presence and absence of the unlabeled ligand and protein complexes were covalently coupled with the cross-linking agent EDC. As shown in Fig. 2, the labeled complex of $\sim 53 \mathrm{kD}$ was absent in reactions containing excess unlabeled ligand. Assuming a molecular mass of $\sim 8 \mathrm{kD}$ for MGSA, the mass of the receptor is deduced to be $\sim 45 \mathrm{kD}$, consistent with the molecular weight from immunoblotting with anti-Fy6.

Analysis of renal DARC ligand binding activity. The DARC binds a broad repertoire of ligands, which is different from that bound by members of the G-protein coupled IL- 8 receptor family $(7,8)$. To demonstrate that the renal isoform of the DARC shares a spectrum of ligand binding that is similar to that of the erythrocyte DARC, we performed radioligand displacement experiments. The binding of ${ }^{125} \mathrm{I}-\mathrm{MGSA}$ to human kidney membranes was completely displaced by excess unlabeled MGSA, IL-8, RANTES, and MCP-1 (Fig. 3). The binding of radiolabeled MGSA was partially antagonized in reactions containing excess unlabeled MIP-1 $\alpha$.

Scatchard analysis was performed to compare the binding affinities of the renal and erythroid isoforms of the DARC. Membrane preparations were incubated with ${ }^{125}$ I-MGSA in the presence of increasing amounts of unlabeled ligand and the ratio of bound to free ligand was plotted as a function of the bound ligand. Ligand binding was linear consistent with a single class of binding sites, and a $K_{\mathrm{D}}$ of $3.5 \pm 0.4 \mathrm{nM}$ (Fig. 4). Coincubation with anti-Fy6 (at a final concentration of $3 \mathrm{nM}$ ) resulted in $88 \%$ inhibition of specific ligand binding but antibodies to the IL-8RA and IL-8RB (100 nM) had no effect on binding.

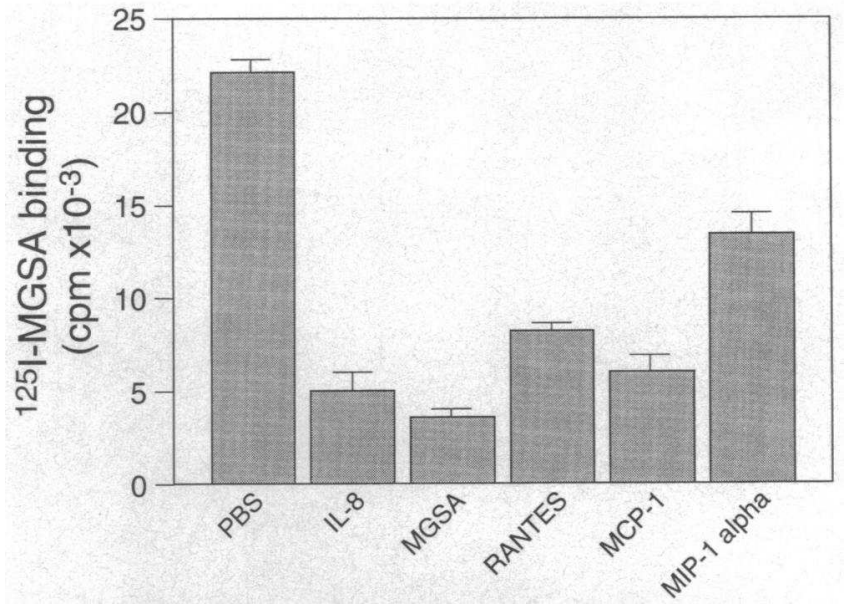

Figure 3. Inhibition of ${ }^{125} \mathrm{I}$-MGSA binding to human kidney membranes. Human kidney membranes $(80 \mu \mathrm{g})$ were incubated with $200 \mathrm{pM}$ radiolabeled MGSA in the presence of $100 \mathrm{nM}$ unlabeled MGSA, IL-8, RANTES, MCP-1, and MIP- $1 \alpha$. The binding reactions were stopped as described in Methods. Data are from three separate experiments and the error bars show the SEM.

Primary structure of renal DARC. Complementary DNA encoding the DARC were isolated from mRNA templates in renal tissues by reverse transcription and amplification with oligonucleotide primers designed from $5^{\prime}$ and $3^{\prime}$ nontranslated regions of the published sequence of the Duffy blood group antigen (19). A PCR product of $\sim 1.2 \mathrm{kbp}$, the size predicted from the mRNA transcript, was subcloned into the TA vector and sequenced. The nucleotide sequence of three clones was identical to that of the published sequence, except for two single base pair differences, which resulted in an alternative nucleotide ( $\mathrm{T}$ instead of $\mathrm{C}$ ) in the first position of codon 181 and ( $\mathrm{A}$ instead of $\mathrm{G}$ ) in the third position of codon number 182. Both sequences encode leucine residues in both positions. Computerized analysis of topologic features using the model of Eisenberg (25) to identify potential transmembrane spanning regions predicts the

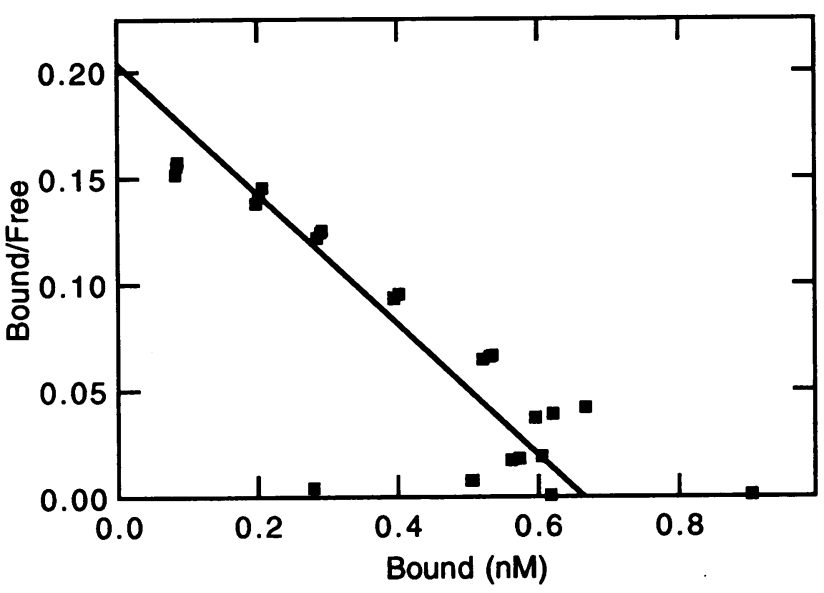

Figure 4. Scatchard analysis of ${ }^{125}$ I-MGSA binding to human kidney membranes. Human kidney membranes $(80 \mu \mathrm{g})$ were incubated with $200 \mathrm{pM}$ radiolabeled MGSA in the presence of increasing concentrations of unlabeled MGSA at $4^{\circ} \mathrm{C}$ for $1 \mathrm{~h}$. Binding was terminated by filtration and counted as described in Methods. 


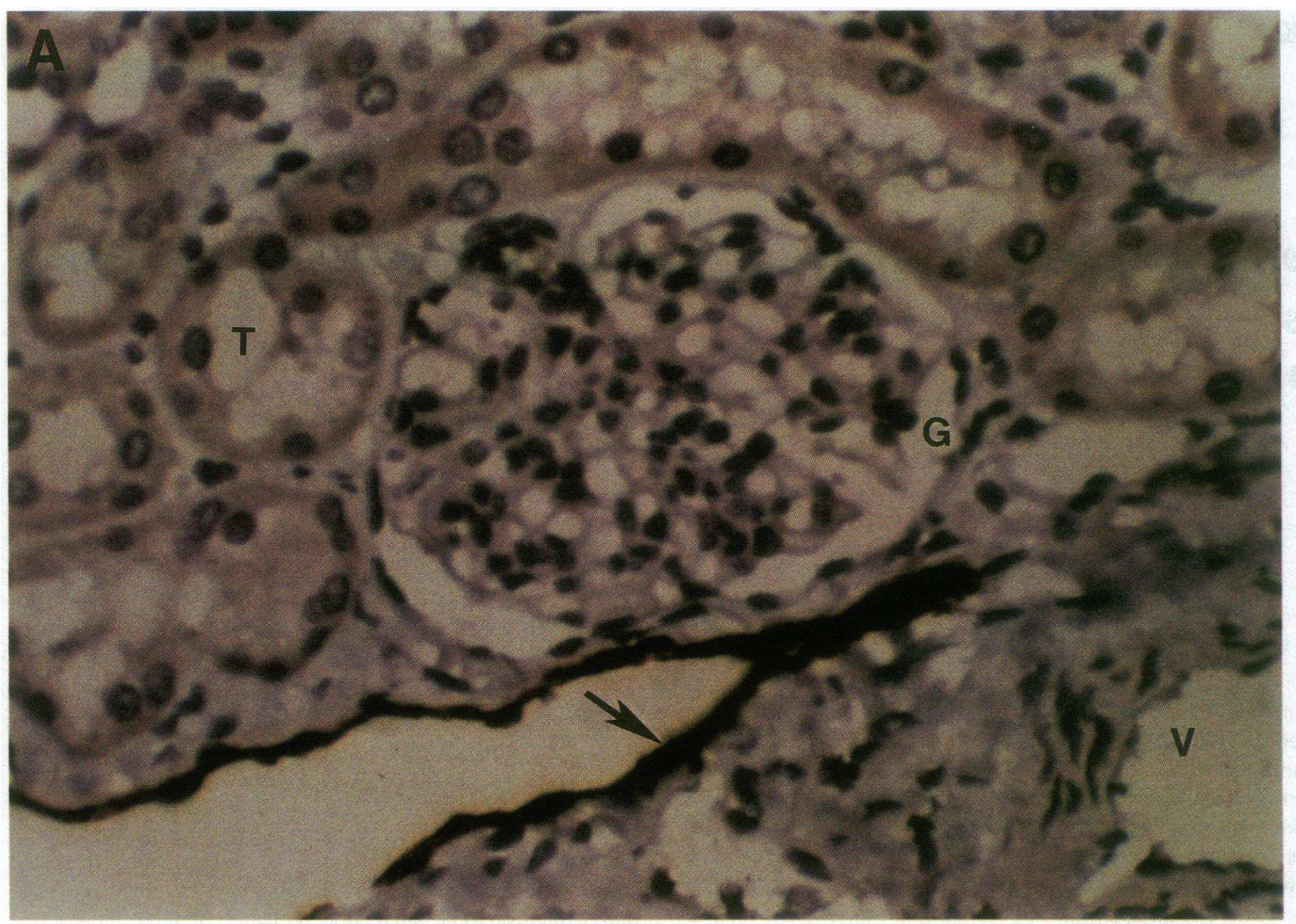

Figure 5. Immunohistochemical localization of the Duffy antigen/chemokine receptor to endothelial cells post-capillary venules in kidney. Sections of formalin-fixed, paraffin-embedded human kidney were processed as described in Methods and incubated with anti-Fy6. After washing, structures binding Fy6 were identified by sequential incubations with avidin-biotin-peroxidase complex and diaminobenzidine. The sections were counter stained with hematoxylin. $A: \times 400, B: \times 100$. A demonstrates intense staining of cells lining a thin walled vascular space that resembles a venule (arrow). There is no significant reactivity with endothelial cells lining a vein $(V)$ or glomerullar capillaries $(G)$ or with endothelial cells of renal tubules $(T) . B$ shows a diseased kidney section that has proliferation of small venules which stain prominently (arrows). Faint reactivity in a glomerulus $(G)$ is localized to erythrocytes. Tubular epithelium $(T)$ lacks significant reactivity.

presence of an amino terminal extracellular domain, seven transmembrane spanning regions, and a cytoplasmic carboxy-terminal tail. These features place the DARC in the superfamily of seven transmembrane domain G-protein coupled receptors (26) together with the other cloned chemokine receptors (3).

Immunohistochemical localization of the DARC in kidney. The kidney is a structurally complex organ composed of blood vessels, glomeruli, and tubules with diverse functions. Immunohistochemistry was performed to identify the cell types that express the DARC. Staining of archival tissues with anti-Fy6 demonstrated that intense immunoreactivity was localized to the endothelial cells lining blood vessels. These structures were identified as venules because they were thin, irregular and lacked a significant mural structure (Fig. 5, $A$ and $B$ ). Staining appeared homogenous along small venules in a pattern most consistent with the staining of endothelial cells along this subset of the vasculature. Arteries, arterioles, capillaries, and veins were negative for staining with anti-Fy6 although they did show staining with anti-CD 34. Renal tubules in the cortex and medulla also lacked significant expression of the receptor, although a faint blush was inconsistently evident in structures resembling proximal tubules.

\section{Discussion}

In this communication we present five separate lines of evidence to suggest that the DARC is expressed on endothelial cells of post capillary venules of human kidney. First, MGSA and antiFy6 bind to molecules of the same molecular mass (Figs. 1 and 2) which is similar, although slightly higher (possibly due to altered glycosylation), than the human erythrocyte DARC (7, 8). Second, membranes prepared from human kidney display the same chemokine binding profile as that displayed by the human erythrocyte DARC (Figs. 3 and 4). Third, the binding of the chemokine MGSA to kidney membranes is inhibited by anti-Fy6, but unaltered by monoclonal antibodies that block the binding of IL-8 and MGSA to IL-8RA and IL-8RB. Fourth, the nucleotide sequence of cDNA encoding the DARC isolated from renal tissue predicted a primary structure identical to that reported for the Duffy blood group antigen (19). Finally, immu- 


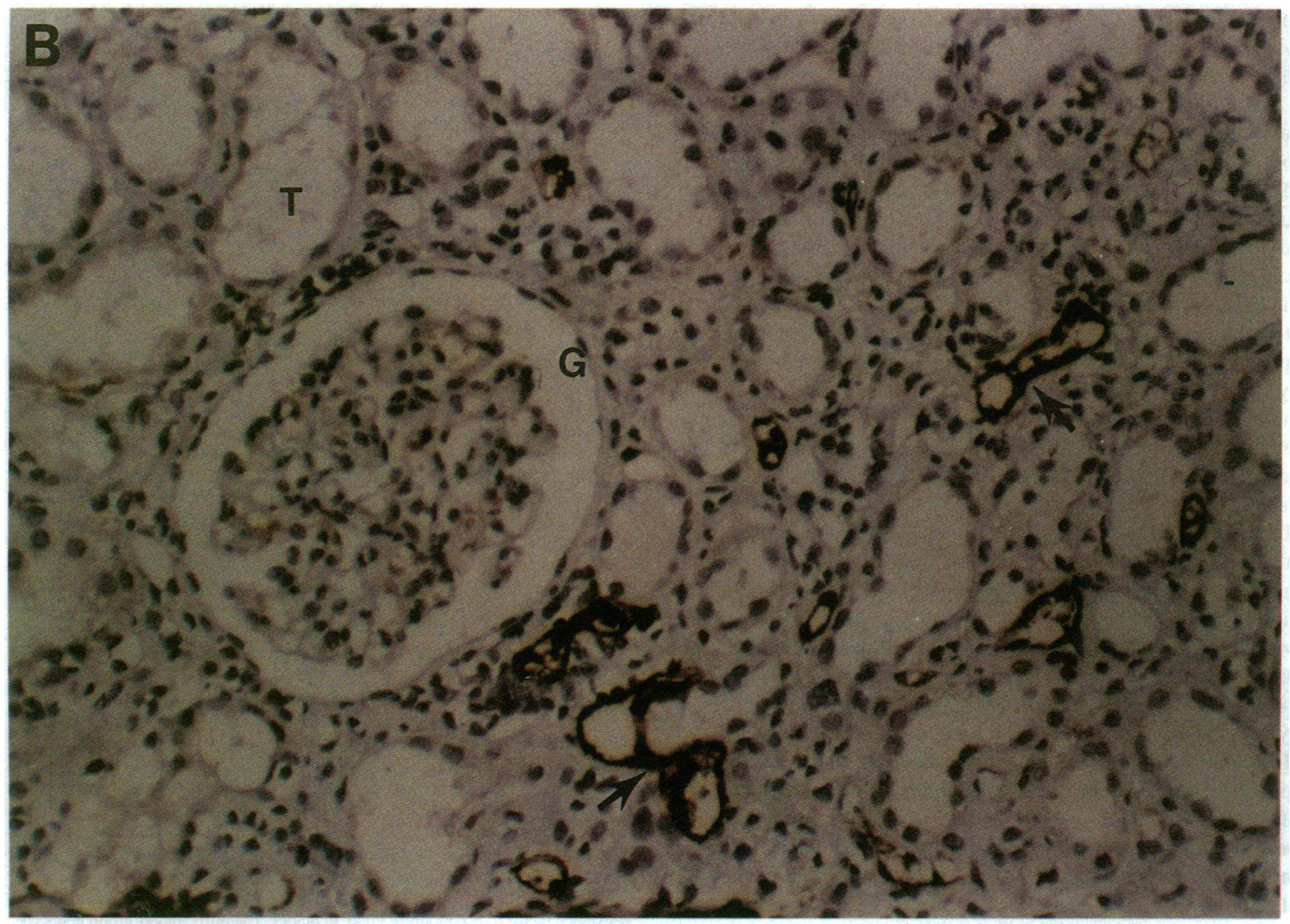

Figure 5 (Continued)

nochemistry with anti-Fy6 localized the expression of the DARC to endothelial cells lining postcapillary venules in sections of human kidney (Fig. 5).

Since the kidney is a highly perfused organ, it is a formal possibility that the biochemical data reflect, at least in part, Duffy antigen derived from erythrocytes. However, the renal and erythroid forms of DARC appear to be distinguishable by immunoblotting analysis (Fig. 1). Furthermore, cells in the kidney that express DARC are clearly identified by immunohistochemistry (Fig. 5, $A$ and $B$ ). These cells, and not erythrocytes, are the source of the mRNA templates encoding DARC that were present in renal tissues. In addition antibodies to glycophorin $\mathrm{A}$, which is expressed in erythrocyte membranes, crossreact as expected with erythrocyte membranes but not with renal membranes (data not shown). Thus, the constellation of findings supports the interpretation that the biochemical data is representative of DARC expressed by non-erythroid cells in the kidney.

Isoforms of other erythrocyte membrane proteins have been described in nonhematopoietic tissues (27-29). These proteins may differ in primary structure from erythroid isoforms because of alternative splicing of pre-mRNA, as occurs for protein 4.1 $(28,29)$, or tissue-specific transcriptional initiation as has been described for murine band 3 (30). Also, tissue specific alternate promoters have been proposed for human band 3 (31) and glycophorin $C(32,33)$, although these have not yet been identified. Proteins in nonhematopoietic tissue that are homologous to ery- throid proteins but are encoded by separate genes have also been described (34). It is clear that investigations into the structure and function of numerous erythrocyte membrane proteins are currently being extended to elucidate their structure and function in nonhematopoietic tissue.

In this report we present evidence that DARC is not specific to erythrocytes but is present along postcapillary venules of the kidney. Furthermore, preliminary data from our laboratories indicate that this protein is expressed along post-capillary venules throughout the body except for liver. The molecular basis of the tissue specific expression of DARC remains to be elucidated. It is clear from the present study that the amino acid sequence of DARC (deduced from cDNA) expressed in kidney is the same as that of DARC expressed on erythrocytes; it is possible, as has been suggested for glycophorin $\mathrm{C}$, that tissue specificity is determined by alternate promoters.

The major finding of this study is the localization of DARC to endothelial cells that line postcapillary venules. Post-capillary venules are a dynamic interface that comprise the site for leukocyte transmigration from the vascular space into the tissue space during inflammation. This process, which is part of the inflammation cascade, is characterized by cytokine-mediated endothelial cell and leukocyte activation, selectin-mediated leukocyte rolling, integrin-mediated leukocyte adherence, and ultimately migration of the leukocyte out of the vascular space into the surrounding tissues along chemokine gradients (35-37). Endo- 
thelial cells, activated by cytokines in vivo, produce IL-8 (20), which may set up a chemotactic gradient favoring transendothelial diapedesis of leukocytes.

The localization of the DARC to endothelial cells of postcapillary venules, together with its ability to bind proinflammatory chemokines, suggests that it may play a major role in this inflammatory cascade. At least three distinct possibilities suggest themselves. First, the DARC of postcapillary venules could be involved in signal transduction that facilitates the interaction between immune cells and the endothelial cell. Second, the receptor could act as a docking protein to concentrate ligands at the cell surface for presentation to specific receptors on the appropriate immune cells. This mechanism has been suggested by Rot (38), who demonstrated that radiolabeled IL-8, injected into rats, binds to post-capillary venules as determined by autoradiography of tissue sections. Interestingly such a role has been recently been described for MIP- $1 \beta$ (39), a member of the chemokine family that does not bind to the erythrocyte chemokine receptor. Alternatively, as suggested by Darbonne et al. (40) for erythrocytes the DARC might act as an intravascular sink, which could bind and inactivate circulating chemokines. This would presumably generate a chemokine gradient with higher concentrations of active chemokines found in the subendothelial matrix (41), possibly bound to sulfated glycans (42). Clearance of IL-8 from the plasma by binding to erythrocytes has been demonstrated in humans treated with IL-1 (43). However, the significance of the erythrocyte chemokine receptor's role as a sink for chemokines must be interpreted in light of the fact that individuals who lack expression of this protein on their erythrocytes (44), yet have no obvious abnormality in the regulation of inflammation. It is also possible that the DARC plays a role in angiogenesis that accompanies inflammation and/ or the growth of tumors as IL-8 has recently been implicated in angiogenesis and endothelial cell migration (45).

In addition to their potential in furthering our understanding of events that modulate the inflammatory cascade, the findings reported here also underscore the concept of molecular heterogeneity of endothelial cells (46). Reactivity with Fy6 antibodies was exclusive to the endothelial cells of postcapillary venules, and was not a feature of endothelial cells of arteries, capillaries or large veins, including umbilical vein, which is unlike the global expression of CD34 and factor VIII molecules by endothelial cells (47). The specificity of the microvascular location of DARC, as well as its binding of proinflammatory chemokines further supports a functional, rather than simply a structural role for this protein.

\section{Acknowledgments}

We thank Dr. Larry Lasky for useful discussions. We thank Judy Hollkamp for help in preparing the manuscript and Paul Eichenberger for technical assistance. We also thank Dr. Frank Serratoni of the Jewish Hospital for providing human kidney for this study and Drs. Gian Re and Julian Garvin for kindly providing RNA from renal tissues.

This work was supported in part by the Agnes Brown Duggan Chair for Oncologic Research, the Humana Fund for Medical Excellence, a National Institutes of Health grant RO1 DK43662, and a grant from the Department of Veteran affairs and the Department of Defense VADOD.

\section{References}

1. Schall, T. J. 1991. Biology of the RANTES/SIS cytokine family. Cytokine. 3:165-183.
2. Oppenheim, J. J., C. O. C. Zachariae, N. Mukaida, and K. Matsushima. 1991. Properties of the novel proinflammatory supergene "intercrine" cytokine family. Annu. Rev. Immunol. 9:617-648.

3. Horuk, R. 1993. Cytokine receptors. In Handbook of Receptors and Channels: G Protein-Coupled Receptors. S. J. Peroutka, editor. CRC Press, Boca Raton 87-93.

4. Holmes, W. E., J. Lee, W. J. Kuang, G. C. Rice, and W. I. Wood. 1991 Structure and functional expression of a human interleukin-8 receptor. Science (Wash. DC). 253:1278-1280.

5. Murphy, P. M., and H. L. Tiffany. 1991. Cloning of complementary DNA encoding a functional human interleukin-8 receptor. Science (Wash. DC). 253:1280-1283.

6. Neote, K., D. DiGregorio, J. Y. Mak, R. Horuk, and T. J. Schall. 1993 Molecular cloning, functional expression, and signaling characteristics of a C-C chemokine receptor. Cell. 72:415-425.

7. Neote, K., W. C. Darbonne, J. Ogez, R. Horuk, and T. J. Schall. 1993. Identification of a promiscous inflammatory peptide receptor on the surface of red blood cells. J. Biol. Chem. 268:12247-12249.

8. Horuk, R., T. J. Colby, W. C. Darbonne, T. J. Schall, and K. Neote. 1993 The human erythrocyte inflammatory peptide (chemokine) receptor. Biochemical characterization, solubilization, and development of a binding assay for the soluble receptor. Biochemistry. 32:5733-5738.

9. Horuk, R., C. E. Chitnis, W. C. Darbonne, T. J. Colby, A. Rybicki, T. J. Hadley, and L. H. Miller. 1993. A receptor for the malarial parasite Plasmodium vivax: the erythrocyte chemokine receptor. Science (Wash. DC). 261:1182-1184.

10. Chaudhuri, A., V. Zbrzezna, J. Polyakova, A. O. Pogo, J. Hesselgesser, and R. Horuk. 1994. Expression of the Duffy antigen in K562 cells: evidence that it is the human erythrocyte chemokine receptor. J. Biol. Chem. 269:78357838 .

11. Cutbush, M., P. L. Mollinson, and D. M. Parkin. 1950. A new human blood group. Nature (Lond.). 165:188-190.

12. Hadley, T. J., P. H. David, M. H. McGinniss, and L. H. Miller. 1984. Identification of an erythrocyte component carrying the duffy blood group $\mathrm{Fy}^{\mathrm{a}}$ antigen. Science (Wash. DC). 223:597-599.

13. Wasniowska, K., P. Eichenberger, F. Kugele, and T. J. Hadley. 1993. Purification of a $28 \mathrm{kD}$ non-aggregating tryptic peptide of the duffy blood group protein. Biochem. Biophys. Res. Commun. 192:366-372.

14. Miller, L. H., S. J. Mason, J. A. Dvorak, M. H. McGinniss, and I. K. Rothman. 1975. Erythrocyte receptors for (Plasmodium knowlesi) malaria: Duffy blood group determinants. Science (Wash. DC). 189:561-563.

15. Miller, L. H., S. J. Mason, D. F. Clyde, and M. H. McGinniss. 1986. The resistance factor to plasmodium vivax in blacks. The duffy-blood-group genotype, FyFy. N. Engl. J. Med. 295:302-304.

16. Barnwell, J. W., M. E. Nichols, and P. Rubenstein. 1987. In vitro evaluation of the role of the Duffy blood group in erythrocyte invasion by Plasmodium vivax. J. Exp. Med. 169:1795-1802.

17. Nichols, M. E., P. Rubinstein, J. Barnwell, S. R. de Cordoba, and R. E. Rubinstein. 1987. A new human duffy blood group specificity defined by a murine monoclonal antibody. J. Exp. Med. 166:776-785.

18. Chaudhuri, A., V. Zbrzezna, C. Johnson, M. Nichols, P. Rubinstein, W. L. Marsh, and A. O. Pogo. 1989. Purification and characterization of an erythrocyte membrane protein complex carrying duffy blood group antigenicity. J. Biol. Chem. 264:13770-13774.

19. Chaudhuri, A., J. Polyakova, V. Zbrzezna, K. Williams, S. Gulati, and A. O. Pogo. 1993. Cloning of glycoprotein D cDNA, which encodes the major subunit of the Duffy blood group system and the receptor for the Plasmodium vivax malaria parasite. Proc. Natl. Acad. Sci. USA. 90:10793-10797.

20. Hébert, C. A., F. W. Luscinskas, J.-M. Kiely, E. A. Luis, W. C. Darbonne, G. L. Bennett, C. C. Liu, M. S. Obin, M. A. Gimbrone, and J. B. Baker. 1990 Endothelial and leukocyte forms of IL-8: conversion by thrombin and interaction with neutrophils. J. Immunol. 145:3033-3040.

21. Steck, T. L., R. S. Weinstein, J. H. Strauss, and D. F. H. Wallach. 1970. Inside-Out Red Cell Membrane vesicles: Preparation and Purification. Science (Wash. DC). 168:255-257.

22. Munson, P., and D. Rodbard. 1980. LIGAND: a versatile computerized approach for characterization of ligand-binding systems. Anal. Biochem. 107:220239.

23. McPherson, G. A. 1983. A practical computer based approach to the analysis of radioligand binding experiments. Comput. Programs Biomed. 17:107114.

24. Chomczynski, P., and N. Sacchi. 1987. Single-step method of RNA isolation by acid guanidinium thiocyanate-phenol-chloroform extraction. Anal. Biochem. 162:156-159.

25. Eisenberg, D. 1984. Three-dimensional structure of membrane and surface proteins. Annu. Rev. Biochem. 53:595-623.

26. Dohlman, H. G., J. Thorner, M. G. Caron, and R. J. Lefkowitz. 1991 Model systems for the study of seven transmembrane-segment receptors. Annu. Rev. Biochem. 60:653-688.

27. Benz, E. J. J., T. K. Tang, F. Baklouti, H. Huang, J. Cho, and V. T Marchesi. 1991. Tissue specific selection of alternatively spliced exons of the 
protein 4.1 gene generates multiple isoforms with altered spectrin actin binding domains. Blood. 78:83a(abstr, suppl 1).

28. Conboy, J., J. Chan, J. A. Chasis, Y. W. Kan, and N. Mohandas. 1991. Tissue- and development-specific alternative RNA splicing regulates isoforms of erythroid membrane protein 4.1. J. Biol. Chem. 266:8273-8280.

29. Conboy, J. G., J. A. Chasis, R. Winardi, G. Tchernia, Y. W. Kan, and N. Mohandas. 1993. An isoform-specific mutation in the protein 4.1 gene results in hereditary elliptocytosis and complete deficiency of protein 4.1 in erythrocytes but not in nonerythroid cells. J. Clin. Invest. 91:77-82.

30. Kopito, R. R., M. A. Andersson, and H. F. Lodish. 1987. Multiple tissue specific sites of transcriptional initiation of the mouse anion transport gene in erythroid and renal cells. Proc. Natl. Acad. Sci. USA. 84:7149-7153.

31. Tanner, M. J. A. 1993. Molecular and cellular biology of the erythrocyte anion exchanger (AE1). Semin. Hematol. 30:34-57.

32. Le Van Kim, C., Y. Colin, and M. T. Mitjavila. 1989. Structure of the promoter region and tissue specificity of the human glycophorin C. J. Biol. Chem. 264:20407-20414.

33. Cartron, J. P., C. Le Van Kim, and Y. Colin. 1993. Glycophorin C and related glycoproteins: structure, function and regulation. Semin. Hematol. 30:152168.

34. Gallagher, P. G., and B. G. Forget. 1993. Spectrin genes in health and disease. Semin. Hematol. 30:4-20.

35. Springer, T. A. 1991. Adhesion receptors of the immune system. Nature (Lond.). 346:425-433.

36. Lasky, L. A. 1992. Selectins: interpreters of cell-specific carbohydrate information during inflammation. Science (Wash. DC). 258:964-969.

37. Springer, T. A. 1994. Traffic signals for lymphocyte recirculation and leukocyte emigration: the multistep paradigm. Cell. 76:301-314.

38. Rot, A. 1992. Endothelial cell binding of NAP-1/IL-8: role in neutrophil emigration. Immunol. Today. 13:291-294.
39. Tanaka, Y, D. H. Adams, S. Hubscher, H. Hirano, U. Siebenlist, and S Shaw. 1993. T cell adhesion induced by proteoglycan-immobilized cytokine MIP1B. Nature (Lond.). 361:79-82.

40. Darbonne, W. C., G. C. Rice, M. A. Mohler, T. Apple, C. A. Hebert, A. J. Valente, and J. B. Baker. 1991. Red blood cells are a sink for interleukin 8, a leukocyte chemotaxin. J. Clin. Invest. 88:1362-1369.

41. Huber, A. R., S. L. Kunkel, R. F. Todd, and S. J. Weiss. 1991. Regulation of transendothelial neutrophil migration by endogenous interleukin-8. Science (Wash. DC). 254:99-102.

42. Strieter, R. M., S. L. Kunkel, H. J. Showell, D. J. Rennick, S. H. Phan, R. A. Ward, and R. M. Marks. 1989. Endothelial cell gene expression of a neutrophil chemotactic factor by TNF- $\alpha$, LPS, and IL-1 $\beta$. Science (Wash. DC). 243:1467-1469.

43. Tilg, H., D. Pape, E. Trehu, L. Shapiro, M. B. Atkins, C. A. Dinarello, and J. W. Mier. 1993. A method for the detection of erythrocyte-bound interleukin8 in humans during interleukin-1 immunotherapy. J. Immunol. Methods. 163:253258.

44. Sanger, R., R. R. Race, and J. A. Jack. 1955. The Duffy blood groups of New York negroes. The phenotype Fy(a-b-). Br. J. Haematol. 1:370-374.

45. Koch, A. E., P. J. Polverini, S. L. Kunkel, L. A. Harlow, L. A. DiPetro, V. M. Elner, S. G. Elner, and R. M. Strieter. 1992. Interleukin-8 as a macrophagederived mediator of angiogenesis. Science (Wash. DC). 258:1798-1801.

46. Swerlick, R. A., K. H. Lee, and T. M. Wick Lawley, T. J. 1992. Human dermal microvascular endothelial but not human umbilical vein endothelial cells express CD36 in vivo and in vitro. J. Immunol. 148:698-705.

47. Fina, L., H. V. Molgaard, D. Robertson, N. J. Bradley, P. Monaghan, D. Delia, D. R. Sutherland, M. A. Baker, and M. F. Greaves. 1990. Expression of the CD34 gene in vascular endothelial cells. Blood 75:2417-2426. 